\title{
Avian population survey in the Floreana highlands: is Darwin's Medium Tree Finch declining in remnant patches of Scalesia forest?
}

\author{
JODY A. O'CONNOR, FRANK J. SULLOWAY and SONIA KLEINDORFER
}

\begin{abstract}
Summary
Island species typically exist in pathogen and predator sparse environments before human settlement, and are particularly vulnerable to the impacts of invasive species. In this study, we used the variable circular-plot method to estimate the density of birds in the highlands of Floreana Island, Galápagos Archipelago, where introduced parasites, predators, and habitat degradation are a known threat to endemic species. We recorded the number of birds seen and heard at 15 locations near Cerro Pajas Volcano in 2004 and 2008, an area that harbours the largest expanse of highland Scalesia forest on Floreana Island. We estimated the change in population density for nine bird species, including five species of Darwin's finches. We specifically address changes in population density for the locally endemic Medium Tree Finch Camarhynchus pauper, which only occurs on Floreana Island and has a small population size. Comparing 2004 and 2008, our study found lower population density in the Medium Tree Finch, but stable population density in Small Tree Finch C. parvulus and Large Tree Finch C. psittacula. Based on data from three additional highland sites surveyed in 2008 , we estimate that the maximum size of the Medium Tree Finch population is 1,620 individuals. In addition to the survey data, we observed breeding males in 2006 and 2008. We found: (1) low nesting success (six out of 63 nests produced fledglings) and high Philornis downsi parasite intensity, and (2) a biased age structure of the breeding population. No breeding males were one year old in 2006, and no males were five years old in either study year, indicating low reproductive success as well as limited lifespan. This research has contributed to the recent re-evaluation by IUCN, which has changed the Red List status of the Medium Tree Finch from 'Vulnerable' to 'Critically Endangered'.
\end{abstract}

\section{Introduction}

Endemic island birds typically exist in small populations within restricted and specialised habitat (Simberloff 1995) where they are 40 times more likely to go extinct than continental species (Johnson and Stattersfield 1990). Birds that are highly adapted to restricted, elevated forest habitats on islands are under a particularly high risk of extinction when their habitat is fragmented via land clearance and/or invaded by introduced species (see Savidge 1987, Johnson and Stattersfield 1990, Steadman 1995). In Hawaii, the cooler high-elevation areas provide refuge for rare endemic honeycreepers (Benning et al. 2002). In contrast, elevated habitats in the Galápagos Islands have high prevalence and infestations of introduced fly larvae parasites Philornis downsi (see Dudaniec et al. 2007, Wiedenfeld et al. 2007), and these highland areas have been extensively cleared for agriculture, leaving only fragmented and invaded habitats for mid-to-high elevation birds.

The $P$. downsi invasion is one of the most recent, yet most significant threats to all landbirds in the Galápagos Islands (Fessl and Tebbich 2002, Causton et al. 2006), including the iconic group of Darwin's finches. Adult $P$. downsi flies lay eggs in bird's nests that hatch into larvae and proceed 
to feed on the blood and body tissues of developing nestlings by external attachment or by entering through the nasal cavity to feed internally (Fessl et al. 2006b, $\mathrm{O}^{\prime}$ Connor et al. in press). Impacts of $P$. downsi parasitism in Darwin's finch nestlings include up to $55 \%$ blood loss, multiple body wounds and infections, increased mortality (Fessl et al. 2006b), reduced fledging success (shown experimentally in Fessl et al. 2006a), and beak deformation of fledglings that survive into adulthood (Galligan and Kleindorfer 2009). The parasite is more prevalent on the three elevated islands with human settlements (Wiedenfeld et al. 2007), such as Floreana Island (which was visited in 1835 by Charles Darwin). With noticeable human impacts even in Darwin's time, Floreana Island now has the longest history of human settlement and avian extinctions in the entire Galápagos archipelago. Native habitat on Floreana Island has been disturbed via agricultural clearance (Lack 1947, Sulloway 1982, Steadman 1986), and invaded by introduced plants (Mauchamp 1997, BirdLife International 2009a), predators (Curry 1986, Baskin 2002, Grant et al. 2005), and avian parasites and infectious diseases (Fessl and Tebbich 2002, Dudaniec et al. 2006, Kleindorfer and Dudaniec 2006, Sharon Deem pers. comm.). To date, three Darwin's finch species have become extinct on Floreana Island, including both the Large Ground Finch Geospiza magnirostris and Sharp-beaked Finch G. nebulosa by about 1870 (reviewed in Sulloway 1982, Steadman 1986) and the reported loss of the Warbler Finch Certhidia fusca by 2004 (see Grant et al. 2005). Once common, the Floreana Mockingbird Nesomimus trifasciatus disappeared from Floreana by 1895 and only survives today on two small islets: Champion and Gardener-by-Floreana (Curry 1986). Floreana Island also supports the only population of the Medium Tree Finch (Lack 1947, Grant 1999), which is restricted to fragmented forest patches in the humid highland area. A recent study has found that, across years, Medium Tree Finch nests have one of the highest $P$. downsi intensity documented in any Darwin finch species, and that $P$. downsi parasitism was responsible for mortality in $41 \%$ of nestlings ( $\mathrm{O}^{\prime}$ Connor et al. 2010).

The preferred nesting tree of the Medium Tree Finch, Scalesia pedunculata, is endangered (Boada 2005) and only remains in small patches within the Floreana highlands. The size of the Medium Tree Finch population is unknown, yet evidence suggests it may be declining due to lack of suitable habitat and high nestling mortality. Adult age structure within the population is also unknown, yet is an essential component for predicting adult survival. Another closely related species, the Large Tree Finch C. psittacula, is also suspected to be declining on Floreana Island (Grant et al. 2005).

In this study we conducted surveys of all birds in the highlands across four sites, three of which contain the largest remnant patches of Scalesia forest, to estimate the maximum population size of several highland bird species. Our objectives were to (I) survey densities of bird species in the highlands of Floreana Island across years, with special reference to Darwin's finches, flycatchers, and yellow warblers; and (2) assess male age structure of nesting Medium Tree Finches across years.

\section{Methods}

\section{Study site: Cerro Pajas Volcano (2004 and 2008)}

We surveyed bird abundance at the base of the Cerro Pajas Volcano (c. 300-40om), which is the highest volcano (maximum elevation $550 \mathrm{~m}$ ) on Floreana Island $\left(173 \mathrm{~km}^{2}, 1^{\circ} 28^{\prime} \mathrm{S}, 90^{\circ} 48^{\prime} \mathrm{W}\right.$; Figure 1 ). The survey was conducted across seven days in mid-February of 2004 and 2008. The Cerro Pajas study site covers an area of approximately $2.4 \mathrm{~km}^{2}$ and is characterised by humid forest habitat, dominated by the tallest endemic Scalesia pedunculata (up to $15 \mathrm{~m}$ high) found on the island (Table 1 ).

\section{Study site: Other highland forest areas (2008 only)}

To gain a better understanding of the entire highland forest bird community, we surveyed three additional highland sites in 2008 (Figure 1). These sites were situated around the base of 


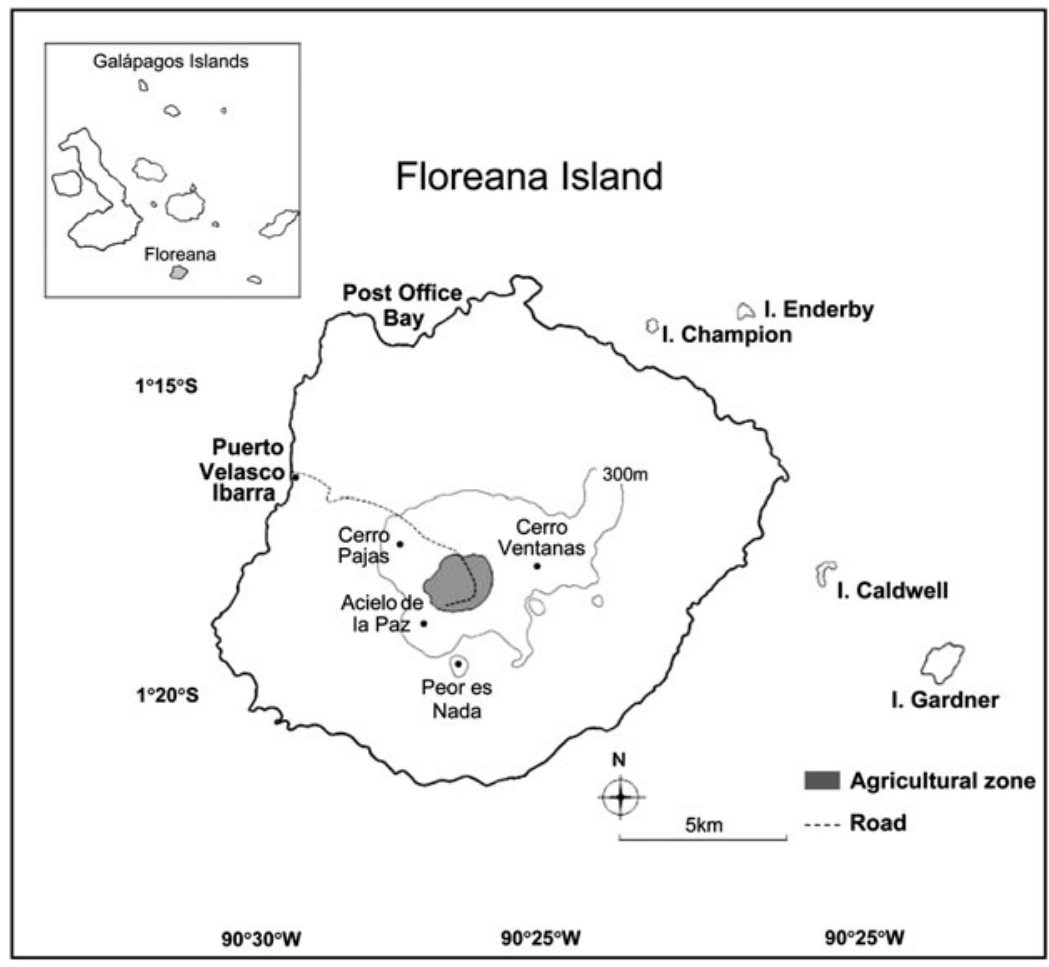

Figure 1. Map of Floreana Island, Galápagos Archipelago, Ecuador. The highlands zone includes all areas within the $300 \mathrm{~m}$ contour line. Site locations and contour lines were established using GPS coordinates and Google Earth Pro ${ }^{\mathrm{TM}}$.

mountains and volcanoes and are considered to be the last patches of native highland forest containing Scalesia (Walter Cruz, Walter Simbaña pers. comm.). The characteristics of each site, including total patch size $\left(\mathrm{km}^{2}\right)$, Scalesia patch size $\left(\mathrm{km}^{2}\right)$, and dominant plant species are shown in Table 1 . Notably, Peor es Nada supports only a small $100 \mathrm{~m} \times 100 \mathrm{~m}$ patch of Scalesia on its north-western slope. Cerro Ventanas does not contain Scalesia, but it does contain native highland shrubs (not trees). Our study has essentially surveyed finch populations in prime habitat in the peak breeding season when song and foraging activity is very high. Birds especially tree finches - do not generally nest in the agricultural area due to lack of suitable nesting substrate, and would only be temporary visitors there to forage on crops.

\section{Survey methods}

We followed protocols of the variable circular plot method to obtain our survey data (see Martin et al. 1997). At Cerro Pajas we sampled from 15 point counts along the trail leading to the inner crater. Fourteen point counts were made at Cerro Ventanas, 11 point counts at Asilo de la Paz, and 12 at Peor es Nada. All point counts were conducted a minimum of $150 \mathrm{~m}$ apart. At each survey point we recorded: (1) GPS co-ordinates, (2) species identity, (3) estimated radial distance of each bird from the observer (in 10-m intervals), and (4) detection method (sight or sound). Birds were recorded up to a distance of $200 \mathrm{~m}$ away, but we only analysed data from within a $20-70 \mathrm{~m}$ radius due to a decline in rates of detection, which varied by species. Surveys were conducted for five minutes at each point, which was sufficient time to identify all birds actively 
Table 1 . Description of vegetation found at each of the four survey sites. The total area with native forest is regarded as any forested area dominated by native tree species. We have noted the occurrence of seven of the most common dominant highland plant species across sites in the following descending order of abundance: (1) Dominant, (2) Common, (3) Patch (common, but only within a specified area in $\mathrm{km}^{2}$ ), (4) Present, (5) Absent. Site sizes were calculated using Google Earth Pro ${ }^{\mathrm{TM}}$.

\begin{tabular}{lllll}
\hline \multicolumn{4}{l}{ Survey site and characteristics } & \\
\cline { 2 - 5 } & Cerro Pajas & Cerro Ventanas & Asilo de la Paz & Peor es Nada \\
\hline Max elevation above sea level & $550 \mathrm{~m}$ & $420 \mathrm{~m}$ & $450 \mathrm{~m}$ & $370 \mathrm{~m}$ \\
Total area with native forest & $2.4 \mathrm{~km}^{2}$ & $2 \mathrm{~km}^{2}$ & $1.3 \mathrm{~km}^{2}$ & $1 \mathrm{~km}^{2}$ \\
Size of Scalesia patch & $2.4 \mathrm{~km}^{2}$ & $0 \mathrm{~km}^{2}$ & $1.3 \mathrm{~km}^{2}$ & $0.01 \mathrm{~km}^{2}$ \\
Height of tallest vegetation & $15 \mathrm{~m}$ & $4 \mathrm{~m}$ & $10 \mathrm{~m}$ & $15 \mathrm{~m}$ \\
Scalesia pedunculata $^{\dagger *}$ & Dominant & Absent & Dominant & Patch \\
Zanthoxylum fagara $^{\dagger *}$ & Common & Present & Common & Present \\
Croton scouleri $^{\dagger *}$ & Common & Dominant & Common & Dominant \\
Macraea laricifolia & Present & Dominant & Present & Dominant \\
Cinchona pubescens $_{\text {Cedrela odorata }}$ & Present & Present & Present & Common \\
Psidium guajava & Absent & Absent & Present & Common \\
\hline
\end{tabular}

${ }^{\dagger}$ Native species
${ }^{*}$ Used as nesting substrate by tree finches (see results)

using the area (this was trialled in a pilot study on Santa Cruz Island in 2000 and repeated in 2008). At each point, the observer surveyed the area facing $0^{\circ}, 90^{\circ}, 180^{\circ}$ and $270^{\circ}$ to eliminate visual or audio bias while facing only one direction. Counts were taken during peak bird activity which was between o6hoo and 12 hoo.

\section{Analysis of population density}

Population density estimates (individual birds $\mathrm{km}^{-2}$ ) and species detectability estimates were initially tested using the software program DISTANCE version 5.0 (Thomas et al. 2006), but our data did not meet the model assumptions/criteria. We also did not obtain the minimum 6o-10o detections per species recommended for calculating accurate density estimates with DISTANCE (Somershoe et al. 2006) because of restrictions imposed by habitat patch sizes/accessibility.

We instead calculated population density using the inflection-point-per-species method (described in Reynolds et al. 1980). We plotted the number of detections of each species within 1o-m concentric bands and determined the distance from the observer at which its rate of detection begins to decline (the inflection point). The detectability of each species is affected by: (I) the ability of its song to be heard through thick vegetation, and (2) its visibility to the observer (due to differences in foraging behaviour). Habitat density analyses only include birds observed at a distance within the inflection point. For the tree finches and ground finches this point was $70 \mathrm{~m}$, but it differed for the remaining species (see Table 2). The number of birds km-2 was determined by calculating the number of birds from each species within each 10-m concentric circle, dividing the number by the total area within each circle, and dividing the density estimate by the number of survey points.

\section{Male age structure in Medium Tree Finches}

We are particularly interested in estimating changes in population density in the Medium Tree Finch, because (I) this species is locally restricted, (2) has high $P$. downsi parasite intensity ( $\mathrm{O}^{\prime}$ Connor et al. 2010), and (3) only six of the 63 monitored nests produced fledglings $\left(\mathrm{O}^{\prime}\right.$ Connor et al. 2010). We examined the age structure of Medium Tree Finches nesting in 
Table 2. Population density estimates for bird species surveyed at Floreana Island highland forest sites in 2004 and 2008. Methods for calculating density are detailed in the methods section. The maximum population size for 2008 was calculated using the mean density (birds $\mathrm{km}^{-2}$ ) across the four sites divided by the total area of native forest $\left(22.5 \mathrm{~km}^{2}\right)$. For the Large Tree Finch, a range in population size was calculated (see results, Cerro Ventanas was excluded from the lower estimate). The inflection point (distance from the observer at which the density of each species declined) was $70 \mathrm{~m}$ for each of the five species of Darwin's finches, $50 \mathrm{~m}$ for the Smooth-billed Ani and Dark-billed Cuckoo, $40 \mathrm{~m}$ for the Yellow Warbler, and $30 \mathrm{~m}$ for the Galápagos Flycatcher.

\begin{tabular}{|c|c|c|c|c|c|c|}
\hline & \multicolumn{5}{|c|}{ Number of birds $\mathrm{km}^{-2}$ : Estimated (Observed) } & \multirow{3}{*}{$\begin{array}{l}\text { Estimated } \\
\text { maximum } \\
\text { highlands } \\
\text { population } \\
\text { size, } 2008\end{array}$} \\
\hline & \multicolumn{2}{|l|}{2004} & \multicolumn{3}{|l|}{2008} & \\
\hline & $\begin{array}{l}\text { Cerro } \\
\text { Pajas }\end{array}$ & $\begin{array}{l}\text { Cerro } \\
\text { Pajas }\end{array}$ & $\begin{array}{l}\text { Cerro } \\
\text { Ventanas }\end{array}$ & $\begin{array}{l}\text { Asilo } \\
\text { de la Paz }\end{array}$ & $\begin{array}{l}\text { Peor } \\
\text { es nada }\end{array}$ & \\
\hline $\begin{array}{l}\text { Small Tree Finch } \\
\text { Camarhynchus paroulus }\end{array}$ & $162(43)$ & $184(57)$ & $129(32)$ & $195(38)$ & $151(32)$ & 3,700 \\
\hline Medium Tree Finch C. pauper & $154(41)$ & $60(19)$ & $61(15)$ & $97(19)$ & $71(15)$ & 1,620 \\
\hline Large Tree Finch C. psittacula & $49(13)$ & $47(1)$ & o & $21(4)$ & $19(4)$ & $450-490$ \\
\hline $\begin{array}{l}\text { Small Ground Finch Geospiza } \\
\text { fuliginosa }\end{array}$ & $132(36)$ & $234(47)$ & $246(61)$ & $206(40)$ & $146(31)$ & 4,680 \\
\hline Medium Ground Finch G. fortis & $26(6)$ & $18(4)$ & $8(2)$ & $5(1)$ & $38(8)$ & 390 \\
\hline $\begin{array}{l}\text { Yellow Warbler Dendroica } \\
\text { petechia }\end{array}$ & $225(18)$ & $690(56)$ & $696(49)$ & $741(41)$ & $812(49)$ & 16,530 \\
\hline $\begin{array}{l}\text { Galápagos Flycatcher Myiarchus } \\
\text { magnirostris }\end{array}$ & $142(8)$ & $401(18)$ & $429(17)$ & $289(9)$ & $88(3)$ & 6,790 \\
\hline Smooth-billed Ani Crotophaga ani & $30(1)$ & $91(3)$ & $18(2)$ & $35(3)$ & $85(8)$ & 1,290 \\
\hline $\begin{array}{l}\text { Dark-billed Cuckoo Coccyzus } \\
\text { melacoryphus }\end{array}$ & o & $34(4)$ & $18(2)$ & $35(8)$ & $18(2)$ & 590 \\
\hline
\end{tabular}

Scalesia forest at the base of Cerro Pajas during the peak finch-breeding period (February-April) of 2006 and 2008. Male tree finches increase the proportion of black on their chins and crowns with each year of annual moult until attaining a fully black head by five years of age (Lack 1947, Grant 1999, Kleindorfer 2007). Therefore, male age is considered to co-vary with male plumage colouration. Each male found singing at a display nest was assigned a unique colour category based on the length of black on the chin $(\mathrm{cm})$ and the extent of black on the crown (see Kleindorfer 2007). Black o (zero) males are yearling males and Black 5 males are five years and older. Females of all species of Darwin's finches remain brown throughout their lives; therefore female plumage colouration gives no indication of age.

Our analysis of male age structure was restricted to males that sang at nests to attract females. We located nests by systematically searching four $100 \mathrm{~m} \times 200 \mathrm{~m}$ study plots at elevations of 300$400 \mathrm{~m}$ within the Cerro Pajas site and locating either (1) singing males with display nests, (2) males building new nests or (3) active nests with a female present. We found 27 Medium Tree Finch males with display nests in 2006, and 36 in 2008. We noted the nesting tree and height for each nest, and GPS co-ordinates were recorded with a hand held Garmin GCX12. Nesting activity was monitored for every unpaired singing male using 20 minute continuous focal sampling at least every second day to determine the status of the nest. At this time, we recorded male colour category.

\section{Results}

Avian population trends in 2004 and 2008 at Cerro Pajas

A total of 344 individuals of nine bird species was counted between years at the Cerro Pajas site within $70 \mathrm{~m}$ point counts and was included in the population density analysis (Table 2). The 
population density (number of birds $\mathrm{km}^{-2}$ ) of some species differed across years, while it remained stable in others (Table 2). Notably, we found that the Medium Tree Finch population declined from 154 birds $\mathrm{km}^{-2}$ in 2004 to 60 birds $\mathrm{km}^{-2}$ in 2008 at the Cerro Pajas site, a reduction of $61 \%$. In 2008, we observed substantially higher densities of six of the other eight species, and collectively these eight species increased their numbers by an average of $280 \%$.

\section{Avian population size across four highland sites in 2008}

In 2008, the density of most species was similar across sites (Table 2) with the exception of Large Tree Finches, which were not seen or heard at Cerro Ventanas. Avian species composition was most different at Peor es Nada where we observed (I) fewer Small Ground Finches and Galápagos Flycatchers Myiarchus magnirostris, and (2) more Medium Ground Finches and Yellow Warblers Dendroica petechia compared with other sites.

\section{Calculating population estimates for the Medium and Large Tree Finch according to habitat suitability}

The highland area of Floreana covers an area of approximately $25 \mathrm{~km}^{2}$. It contains an inner region of approximately $2.5 \mathrm{~km}^{2}$ that has been cleared for agriculture. The Floreana highlands thus contain a $22.5 \mathrm{~km}^{2}$ uncleared area that may contain suitable forest habitat for Medium Tree Finches. Scalesia dominated forest is estimated at $3.71 \mathrm{~km}^{2}$ (see Table 1 ).

A mean of 72 Medium Tree Finches $\mathrm{km}^{-2}$ was observed in surveyed forest habitat (calculated as an average over the four survey sites in 2008). Using $22.5 \mathrm{~km}^{2}$ as the maximum habitat size, we estimate that the entire Medium Tree Finch population on Floreana Island consists of up to 1,620 individuals (Table 2). Using the same reasoning, the Large Tree Finch population has a mean of 22 finches $\mathrm{km}^{-2}$ with up to 490 individuals on Floreana Island in 2008. However, Large Tree Finches were not detected at Cerro Ventanas. If we exclude this area from our calculation, then the maximum number of Large Tree Finches on Floreana Island in 2008 was 450 (Table 2).

\section{Male age structure in Medium Tree Finches}

We recorded data from 63 males that were observed singing at 77 display nests to attract a female. Some males built multiple display nests. Most nests ( $83 \%)$ were built in S. pedunculata $(n=63)$, $14 \%$ in Z. fagara $(n=11), 2 \%$ in C. scouleri $(n=2)$, and $1 \%$ in guava $(n=1)$. Mean nest height was $6.15 \mathrm{~m}$ ( $\pm \mathrm{SE}$ 0.22), though nest height ranged from 3 to $12 \mathrm{~m}$ high. Most nesting males were young ( $88 \%$ of nesting males were Black category o-3). Only $12 \%$ of males were in category Black 4, and no Black 5 males were seen or mist-netted. There was a significant difference in the age structure of nesting males between 2006 and 2008: no Black o males were found in 2006 and more Black 1 males were found in 2008 (Likelihood ratio $=21.79, \mathrm{df}=4$, $P<0.001$ ) (Figure 2). This finding suggests that breeding did not occur in 2005, which was a drought year in the archipelago.

\section{Discussion}

\section{Population trends in tree finches}

This is the first study to estimate the population size/density and range restrictions of any highland bird community in the Galápagos Islands. Of the three Camarhynchus tree finch species observed in the Floreana survey, Small Tree Finches were the most common (Table 2). Medium and Large Tree Finches were observed at lower densities relative to Small Tree Finches using both point count sampling and non-targeted mist netting (Christensen and Kleindorfer unpubl. data). 


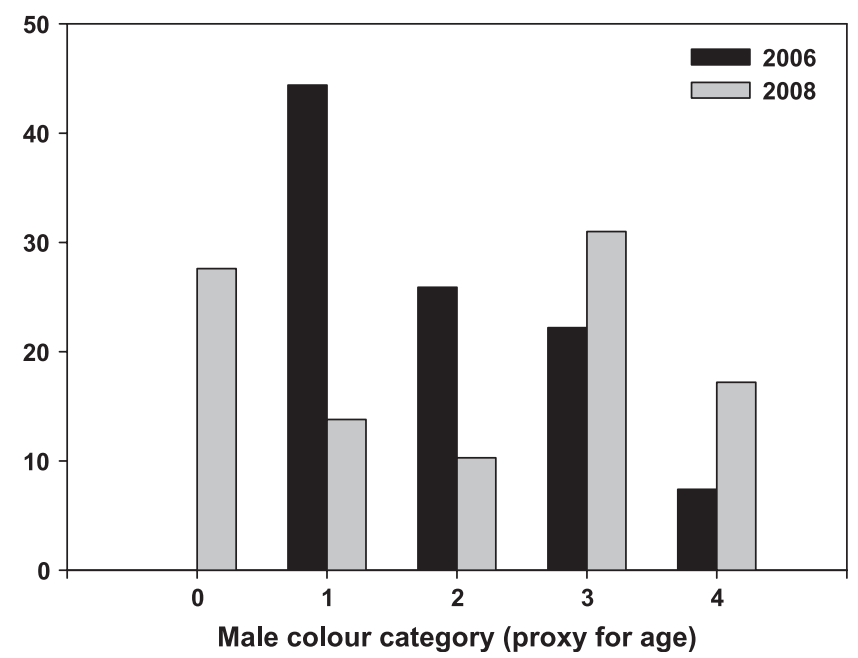

Figure 2. Change in the percentage of male colour categories at active Medium Tree Finch nests in the Floreana highlands between 2006 and 2008. Note that there were no Black o (young) males in 2006, which suggests unsuccessful breeding in the previous year(s). No Black 5 (old) males were observed in either study year.

Large Tree Finches were always the least common tree finch species in both the point count and mist netting surveys. This species warrants close monitoring on Floreana Island because it exhibits three hallmark features of a species that could be on a trajectory to extinction: (I) small population size: $<450$ individuals, (2) large body size (which is associated with higher $P$. downsi parasitism levels), and (3) more specialist foraging behaviour (Bennett and Owens 1997, 2002; discussed in Christensen and Kleindorfer 2008). In addition, we know that only one Large Tree Finch nest that we monitored over two years produced fledglings, and this nest had high parasite intensity (50 P. downsi larvae in the nest; $\mathrm{O}^{\prime}$ Connor et al. 2010).

Although the Small and Large Tree Finch populations appear to be stable, the intermediate-sized form of these two species - the Medium Tree Finch - has declined in numbers. By 2008, the Medium Tree Finch population at Cerro Pajas had dropped to $39 \%$ of its size in 2004, which is equivalent to a decline of $\sim 15 \%$ per year. Natural populations of birds are known to fluctuate in numbers across years (Holmes and Sherry 2001), and declining populations can recover from major losses (Roth and Johnson 1993, Holmes and Sherry 2001, Hale and Briskie 2009). However, in the case of the Medium Tree Finch, the probable causes for its decline (introduced parasites and predators, and habitat loss) are not likely to subside without concentrated effort. Fledging success was lower in 2008 (a wet year) compared with 2006 (a dry year) despite abundant resources, high bird nesting activity, and large clutch size. Lower fledging success in 2008 compared with 2006 was explained by higher levels of nestling depredation and parasitism $\left(\mathrm{O}^{\prime}\right.$ Connor et al. 2010). The entire Medium Tree Finch population currently consists of a maximum 1,620 individuals, which is significantly smaller than it was 50-100 years ago (Kleindorfer and Sulloway in prep.). This finding may be explained by a combination of low nesting success and low adult survival. In a recent comparison of $P$. downsi parasite intensity in three Floreana Island tree finch species, $\mathrm{O}^{\prime}$ Connor et al. (2010) found that the larger bodied Medium and Large Tree Finches had higher parasite intensity than the Small Tree Finch. The study also found that Medium Tree Finches had higher $P$. downsi parasite intensity than expected based on body mass and that parasitism was responsible for $41 \%$ of nestling mortality. The Medium Tree Finch has since been uplisted from 'Vulnerable' to 'Critically Endangered' on the 2009 IUCN Red List (Birdlife International 20ogb). 


\section{Tree finch habitat on Floreana Island}

We estimated maximum population sizes of each species according to their densities $\mathrm{km}^{-2}$ across sites in 2008, multiplied by the area of native forest area. However not all of the maximum uncleared highland forest area used to calculate population range/size may be suitable tree finch habitat, as non-Scalesia forest is of considerably lower height (eg., Cerro Ventanas, maximum $4 \mathrm{~m}$ ) (Table I) and lower vegetation density. For example, Large Tree Finches were only observed at sites with tall trees, and where Scalesia is present (Table 2). Medium Tree Finches nested at a mean height of $6.15 \mathrm{~m}$, and $83 \%$ of their nests were in Scalesia trees (at Cerro Pajas). Displacement of native Scalesia forest by exotic fruit trees was identified as a conservation problem on Floreana as early as 1957 (Eibl-Eibesfeldt 1959), and the species now remains only in small patches because of agricultural clearance, competition from invasive plants, and destruction by introduced mammals.

\section{Male age structure in Medium Tree Finches}

Of the 63 Medium Tree Finch males observed singing at nests to attract females, most were less than four years old (see Figure 2), as indicated by the extent of black colouration in crown and chin plumage. Recent studies have found that older male Small Tree Finches have higher pairing success compared with young males of the same species (Kleindorfer 2007, Kleindorfer et al. 2009). Kleindorfer (2007) also found that older males built more concealed nests that were less likely to be depredated and experienced higher fledging success. Thus, the scarcity of older Medium Tree Finch males in the population may negatively influence nesting outcome if male age predicts nesting success.

Our finding of no young (Black o) males in 2006 suggests unsuccessful breeding in the dry year of 2005 (see Dudaniec et al. 2007 for rainfall data). Many two-year-old (Black I) males were found in 2008 and may represent a cohort that fledged in 2006. Few Black 4 and no Black 5 males were observed, which suggests that adults are not surviving past $4-5$ years of age. The overall young age structure of the Medium Tree Finch population signifies that adult males are not generally surviving to full maturity (five years or more).

\section{Population trends in other bird species}

Significant changes in Galápagos finch population sizes have been reported from small and lowelevation islands such as Daphne Major where selection pressures are high and extremely variable across years (Grant 1999). The six elevated Galápagos islands with forest highland regions receive higher and more consistent annual rainfall (Wiedenfeld et al. 2007), which should support more stable bird population sizes. Here, we show that some bird species experienced rapid and dramatic population fluctuations in as little as four years on the elevated island of Floreana. Between 2004 and 2008 at the Cerro Pajas site, the Medium Tree Finch declined in numbers and the density of all other species either increased or remained relatively stable (Table 2). The ratio of change in densities of all other species in Table 2, compared to the Medium Tree Finch, is 7.2 to 1 . Thus the Medium Tree Finch population, as of 2008 , represented about $14 \%$ of what would be expected based on the more favourable ecological conditions that year, as reflected in the population sizes of other species. Warblers and flycatchers are insectivorous and may have been more commonly observed in 2008 because of an increase in insect abundance due to heavier rainfall. Small Ground Finches have the widest foraging breadth among Darwin's finches, which enables them to exploit modified habitats from which more specialised finches could be excluded (see also Kleindorfer et al. 2006, Kleindorfer and Mitchell 2009, Sulloway and Kleindorfer in prep. for a discussion of habitat use and range expansion on Santa Cruz Island). The increase in Small Ground Finch abundance may be due to their expansion into the highlands 
during a period of drought, where they can use the available food resources given their generalist foraging behaviour and diet.

The Vegetarian Finch Platyspiza crassirostris was not detected in surveys, though one female was observed at the Cerro Pajas site by J.O'C in 2008. The Vermilion Flycatcher Pyrocephalus rubinus, once considered relatively common in the highlands of Floreana Island (Edwin Egas and Walter Cruz pers. comm.), was not detected in our bird surveys, although two Vermilion Flycatchers were observed by S.K. in 2004 at the Cerro Pajas site while conducting other fieldwork. Finally, although the Warbler Finch Certhidea fusca was considered locally extinct by 2004 (Grant et al. 2005), we heard a male singing in 2008 (approximately $20 \mathrm{~m}$ high in a Cedrela odorata tree at Asilo de la Paz).

\section{Conclusion}

Here we show that the sole population of Darwin's Medium Tree Finch is small, declining, and at risk of extinction. Three other species (Vermilion Flycatcher, Vegetarian Finch, and Warbler Finch), once common in the Floreana highlands, have also become extremely rare. The Galápagos National Park has recently implemented programmes to control and eradicate invasive plants and feral goats within the Floreana highlands. To help prevent another local avian extinction on the island, there is a need for effective P. downsi parasite and rodent predator control, as well as regeneration and expansion of the endemic Scalesia forest.

\section{Acknowledgements}

This paper is contribution number 2005 of the Charles Darwin Foundation for the Galápagos Islands. We are grateful to the Charles Darwin Research Station and Galápagos National Park Service for the opportunity to work on the Galápagos, and for logistical support. This work was generously supported by Flinders University (Research Establishment Grant), Conservation International, the American Bird Conservancy, the Winifred Violet Scott Trust with awards to SK, and also Flinders University (travel grant), the Royal Zoological Society of South Australia, Birdfair/RSPB Research Fund for Endangered Birds and the Australian Federation of University Women (SA) with awards to JO'C. TAME airlines provided reduced airfares. We thank Santos Humberto for field assistance, Walter Cruz and Michael Dvorak for advising JO'C on fieldwork methodology, and Chris Holden for assistance with DISTANCE software.

\section{References}

Baskin, Y. (2002) A plague of rats and rubber vines: The growing threat of species invasions. Washington DC: Island Press.

Bennett, P. M. and Owens, I. P. F. (1997) Variation in extinction risk among birds: chance or evolutionary predisposition? Proc. R. Soc. Lond. B. 264: 401-408.

Bennett, P. M. and Owens, I. P. F. (2002) Evolutionary ecology of birds: Life history, mating system and extinction. New York: Oxford University Press.

Benning, T. L., Lapointe, D., Atkinson, C. T. and Vitousek, P. M. (2002) Interactions of climate change with biological invasions and land use in the Hawaiian Islands:
Modeling the fate of endemic birds using geographic information system. Proc. Natl. Acad. Sci. USA 99: 14246-14249.

BirdLife International. (2009a). Important Bird Area factsheet: Isla Floreana, Ecuador. Downloaded from the Data Zone at http:// www.birdlife.org on $15 / 5 / 2009$

BirdLife International. (2009b). Species factsheet: Camarhynchus pauper. Downloaded from http://www.birdlife.org on 15/5/2009

Boada, R. (2005) Insects associated with endangered plants in the Galápagos Islands, Ecuador. Entomotropica 20: 77-88.

Causton, C. E., Peck, S. B., Sinclair, B. J., Roque-Albelo, L., Hodgson, C. J. and 
Landry, B. (2006) Alien insects: threats and implications for the conservation of the Galápagos Islands. Ann. Entomol. Soc. Am. 99: 121-143.

Christensen, R. and Kleindorfer, S. (2008) Jackof-all-trades or master of one? Variation in foraging specialisation across years in Darwin's Tree Finches (Camarhynchus spp.). J. Ornithol. doi:10.1007/s10336-008-0358-y.

Curry, R. L. (1986) Whatever happened to the Floreana Mockingbird? Not. Galáp. 43: 13-15.

Dudaniec, R. Y., Fessl, B. and Kleindorfer, S. (2007) Interannual and interspecific variation on intensity of the parasitic fly, Philornis downsi, in Darwin's finches. Biol. Conserv. 139: 325-332.

Dudaniec, R. Y., Kleindorfer, S. and Fessl, B. (2006) Effects of the introduced ectoparasite Philornis downsi on haemoglobin level and nestling survival in Darwin's small ground finch (Geospiza fuliginosa). Austral Ecol. 31: 88-94.

Eibl-Eibesfeldt, I. (1959) Survey of the Galápagos Islands. Paris: UNESCO (UNESCO Missions Report No. 8).

Fessl, B., Kleindorfer, S. and Tebbich, S. (2006a) An experimental study on the effects of an introduced parasite in Darwin's finches. Biol. Conserv. 127: 55-61.

Fessl, B., Sinclair, B. J. and Kleindorfer, S. (2006b) The life cycle of Philornis downsi (Diptera: Muscidae) parasitizing Darwin's finches and its impacts on nestling survival. Parasitology 133: 739-747.

Fessl, B. and Tebbich, S. (2002) Philornis downsi - a recently discovered parasite on the Galápagos archipelago - a threat for Darwin's finches? Ibis 144: 445-451.

Galligan, T. H. and Kleindorfer, S. (2009) Naris and beak malformation caused by the parasitic fly, Philornis downsi (Diptera: Muscidae), in Darwin's small ground finch, Geospiza fuliginosa (Passeriformes: Emberizidae). Biol. J. Linn. Soc. 98: 577-585.

Grant, P. R. (1999) Ecology and evolution of Darwin's finches. Princeton: Princeton University Press.

Grant, P. R., Grant, B. R., Petren, K. and Keller, L. F. (2005) Extinction behind our backs: the possible fate of one of the Darwin's finch species on Isla Floreana, Galápagos. Biol. Conserv. 122: 499-503.
Hale, K. A. and Briskie, J. V. (2009) Rapid recovery of an island population of the threatened South Island Saddleback Philesturnus c. carunculatus after a pathogen outbreak. Bird Conserv. Internatn. 19: 239253.

Holmes, R. T. and Sherry, T. W. (200I) Thirty-year bird population trends in an unfragmented temperate deciduous forest: Importance of habitat change. Auk. 118: 589-609.

Johnson, T. H. and Stattersfield, A. J. (1990) A global review of island endemic birds. Ibis 132: $167-180$.

Kleindorfer, S. (2007) Nesting success in Darwin's small tree finch (Camarhynchus parvulus): Evidence of female preference for older males and more concealed nests. Anim. Behav. 74: 795-804.

Kleindorfer, S. \& Dudaniec, R. Y. (2006) Increasing prevalence of avian poxvirus in Darwin's finches and its effect on male pairing success. Journal of Avian Biology 37: 69-76.

Kleindorfer, S., Chapman, T. W., Winkler, H. and Sulloway, F. J. (2006) Adaptive divergence in contiguous populations of Darwin's small ground finch (Geospiza fuliginosa). Evol. Ecol. Res. 8: 357-372.

Kleindorfer, S. and Mitchell, J. G. (2009) Biological networks: Rainforests, coral reefs and the Galápagos Islands. Pp. 85-104 in P. R. Kleindorfer and J. Wind, eds. Network challenge: the strategy, profit, and risk in an interlinked world. Pennsylvania, US: Wharton School Publishing.

Kleindorfer, S., Sulloway, F. J. and O'Connor, J. (2009) Mixed species nesting associations in Darwin's tree finches: Nesting pattern predicts breeding performance. Biol. J. Linn. Soc. 98: 313-324.

Lack, D. (1947) Darwin's finches. Cambridge, UK: Cambridge University Press.

Martin, T. E., Paine, C. R., Conway, C. J., Hochachka, W. M., Allen, P. and Jenkins, W. (1997) BBIRD field protocol. Missoula, Montana, USA: University of Montana Cooperative Wildlife Research Unit, US Geological Survey.

Mauchamp, A. (1997) Threats from alien species in the Galápagos Islands. Conserv. Biol. 11: 260-263. 
O'Connor, J. A., Robertson, J. and Kleindorfer, S. (in press) Video analysis of hostparasite interactions in Darwin's finch nests. Oryx

O'Connor, J. A., Sulloway, F. J., Robertson, J. and Kleindorfer, S. (2010) Philornis downsi parasitism is the primary cause of nestling mortality in the critically endangered Darwin's medium tree finch (Camarhynchus pauper). Biodivers. Conserv. 19: 853866.

Reynolds, R. T., Scott, J. M. and Nussbaum, R. A. (1980) A variable circular plot method for estimating bird numbers. Condor 82: 309-313.

Roth, R. R. and Johnson, R. K. (1993) Longterm dynamics of a wood thrush population breeding in a forest fragment. Auk I10: $37-48$.

Savidge, J. A. (1987) Extinction of an island forest avifauna by an introduced snake. Ecology 68: 660-668.

Simberloff, D. (1995) Habitat fragmentation and population extinction of birds. Ibis 137: 105-111.

Somershoe, S. G., Twedt, D. J. and Reid, B. (2006) Combining breeding bird survey and distance sampling to estimate density of migrant and breeding birds. Condor 108: 691-699.

Steadman, D. (1986) Holocene vertebrate fossils from Isla Floreana, Galápagos. Washinton DC: Smithsonian Institution Press (Smithsonian Contributions to Zoology no. 413).

Steadman, D. W. (1995) Prehistoric extinctions of Pacific Island birds: biodiversity meets zooarchaeology. Science 267: 1123-1131.

Sulloway, F. J. (1982) The Beagle collections of Darwin's finches (Geospizinae). Bull. Br. Mus. (Nat. Hist.) Zool. Ser. 43: 49-94.

Thomas, L., Laake, J. L., Strindberg, S., Marques, F. F. C., Buckland, S. T., Borchers, D. L., Anderson, D. R., Burnham, K. P., Hedley, S. L., Pollard, J. H., Bishop, J. R. B. and Marques, T. A. (2006) Distance 5.0 Release 2. St. Andrews, UK: Research Unit for Wildlife Population Assessment, University of St. Andrews.

Wiedenfeld, D. A., Jimènez, G., Fessl, B., Kleindorfer, S. and Valerezo, J. C. (2007) Distribution of the introduced parasitic fly Philornis downsi (Diptera, Muscidae) in the Galápagos Islands. Pac. Conserv. Biol. 13: 14-19.

\section{JODY A. O'CONNOR, SONIA KLEINDORFER*}

Flinders University, School of Biological Sciences, GPO Box 2100, Adelaide, SA, 5001, Australia.

\section{FRANK J. SULLOWAY}

University of California, Institute of Personality and Social Research, 4125 Tolman Hall, Berkeley, CA, 94720, USA.

*Author for correspondence; email: sonia.kleindorfer@flinders.edu.au

Received I June 2009; revision accepted 5 January 2010; Published online 6 April 2010 